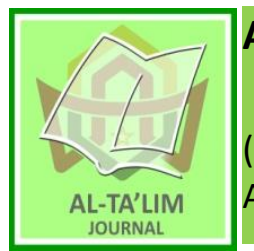

AL-TA'LIM JOURNAL, 25 (2), 2018, (135-143)

(Print ISSN 1410-7546 Online ISSN 2355-7893)

Available online at http://journal.tarbiyahiainib.ac.id/index.php/attalim

\title{
The Development of Arabic Learning Model by Using Multimedia of Computer at UIN STS Jambi
}

Received: $13^{\text {th }}$ January 2018; Revised:01 ${ }^{\text {st }}$ March 2018; Accepted: $24^{\text {th }}$ July 2018

Permalink/DOI: http://dx.doi.org/10.15548/jt.v25i2.371

\section{Yogia Prihartini *)}

Universitas Islam Negeri, Jambi, Indonesia.

E-Mail: yogia_prihartini@yahoo.com

\section{Wahyudi}

Universitas Negeri Padang, Indonesia.

E-Mail: wahyudi1000data@gmail.com

\section{Aliasar}

Universitas Negeri Padang, Indonesia. E-Mail: aliasarkoto19@gmail.com

\section{Mukhaiyar \\ Universitas Negeri Padang, Indonesia. \\ E-Mail: jmkhaiyar@yahoo.com}

\section{Ungsi AOM}

Universitas Negeri Padang, Indonesia.

E-Mail: ungsiaom@yahoo.com

*) Corresponding Author

\begin{abstract}
This research and development result in a learning model that could be used to improve oral communication that was divided into five different learning phase, which is, orientation phase, ordering command phase, role exchange phase, structured practice phase, and guided practice phase. It could also improve one's understanding of arabic grammar/qawaid (nahwu wa sharfi) which consists of elements in Arabic language that consist of Letters (harf), Words (kalimatu), Sentences (jumlatu), sibhuljumlah and articles (uslub) and fit into Arabic grammar. The result of this study implies that development result study model emphasize in college students' activities in their learning process. The learning process done by the lecturers using Arabic language as the language of instruction started by the pronunciation of the vocabularies and it's demonstration without translating it into Bahasa Indonesia. After they were capable of demonstrating the acquired vocabularies, college students trained in reproducing the language orally using question and answer activities, whether structurally, or guided. The study results showed that the quality of this multimedia teaching of Arabic language fall into the 'fine' category, acquiring average score of 43.92 and ideal percentage of $87.85 \%$.
\end{abstract}

Key words: Arabic learning; model; multimedia of computer.

How to cite: Prihartini, Y., Wahyudi, W., Aliasar, A., Mukhaiyar, M., \& AOM, U. (2018). The development of Arabic learning model by using multimedia of computer at UIN STS Jambi. Al-Ta Lim Journal, 25(2). doi:http://dx.doi.org/10.15548/jt.v25i2.371

\section{INTRODUCTION}

One of the efforts to increase the quality in learning process, especially the Arabic language, with the curriculum renewal success indicator is shown by the change of pattern in learning activities. Indonesian's Arabic learning process, as expressed by Abdalla (2010); Al-Shemri (2005); TahaThomure (2008) that before the 1976 curriculum was enacted for Islamic schools in the department of religion environment, Arabic language teaching process was done by traditional system (furu'yah) (Rehani, 2015). This system was divided into several subjects which is, nahwu, sharaf, qira'ah, insya', muhadashah and each is a standalone with their own module and schedule. However, there was a weakness contained in this system, which result in the imbalance of student's grasp of Arabic knowledge, and became the source of student's lack in language development (Mohamed, Elbert, \& Landerl, 2011; Ryding, 2013; Wekke, 2015). 
Learning Arabic, as with learning any other foreign languages, provide its own difficulties. These difficulties lies in the nature of foreign language compared to one's native language either in the vocal sound or written aspects. Meanwhile, the mastery of Arabic as a foreign language is a must in universities such as UIN Sultan Thaha Saifuddin Jambi.

The use of media, as said by Azhar (2004) in language education, is contrasted with the theory which states that the wholesome amount of knowledge, skill, and attitude possessed by someone is in its highest and most from his or her sight, and experience, while the rest are from hearing and everything else. This also applies to the learning or Arabic, where the four linguistic skills should be taught in various ways so that it would not bore the college students, and feel monotonous about what they learned from their lecturers. In this case, the use of media becomes important since media could be an effective medium for learning, and to make learning easier. The study of linguistic will be much more attractive when better delivered.

There are also a lot of times when, in order to fulfill the curriculum target, the lecturers forced the college students by giving them a huge amount of materials without considering their understanding of the materials, or whether they are interested in it. Even though that a monotonous studying environment would cause discomfort and stress. This condition will make it difficult to achieve an optimal study result and to improve their interest in learning Arabic.

The media that are used in teaching Arabic so far is still quite elementary, involving only textbooks, the whiteboard and the boardmarker (Samy, 2006). The lecturers still found some difficulties in delivering the materials in an attractive manner to the college students in order for them to effectively understand the materials. That is why, a new and more suitable method and media is required to make learning Arabic interesting, able to maximize the use of students left and right part of their brain, and able to achieve its aim in learning Arabic, which in turn will give a sense of accomplishment to the students (Hanifah, 2011; Mahmudah, 2018).

Meanwhile, the existing modules are still incomprehensible by most of the college students to understand directly. The psychological principle and the theoretical design of a module is sometimes inapplicable. This results in students having difficulties in understanding the given materials and lead to boredom. We feel the lack of Arabic learning software which can be used by the lecturers so the students could be more active and independent.

Adobe flash, or macromedia flash, could be the first alternative to solve the problem mentioned above. Adobe flash software combines the concept of learning with audiovisual technology which could produce new features that could be used for learning process (Abdullah \& Pathan, 2013; Godwin-Jones, 2012). Multimedia based study will be able to deliver the learning material in an interactive and nonmonotonous way so that the students can understand better. Students can also learn about specific materials their own way by using multimedia-enhanced computer programs. Multimedia technology has the ability to make learning more effective and attractive (Aldalalah, Fong, \& Ababneh, 2010).

Based on the early observation done in UIN Sultan Thaha Saifuddin Jambi, there are numerous problems in learning Arabic, such as: 1) as a mandatory subject in schools and universities, the learning condition of Arabic language is still faced with various problems and challenges, in order for the ideal Arabic learning (the mastery of four linguistic abilities) can't be wholly done. England, Wahba, \& Taha (2014) propose three teaching obstacles of Arabic language: First, educational factor, Arabic language teaching process is still relatively unsupported with mandatory teaching factors such as curriculum (this includes orientation and aim, 
the volume of materials, teaching system, and evaluation system), teachers and lecturers factors, and supportive teaching media factors; Second, social and cultural factors, which Arabic language learning map commonly in an unsuitable social environment. There are serious difficulties in creating a conducive and supportive environment for ensuring the success of learning Arabic; Third, the Arabic language's own linguistic factor. So far, college students tend to think that studying Arabic is much harder than learning other foreign language (Amaliati, 2014; Firmansyah, 2015). 2) The implementation and non-implementation problem of learning Arabic in Indonesia, such as (a) the low starting abilities of college students, (b) the materials of learning Arabic language, (c) the low qualification of arabis lecturers, (d) Arabic language study which focuses more on the learning (ta'allum) aspect rather than the acquisition (iktisab) aspect. Studying process which focuses on learning aspect will produce college students whom are able to understand the forms of Arabic, but unable to recreate tha language as a medium of communication; (e) the method or learning strategy is monotonous. The lecturers tend to use the grammar-translate method. This method is easily applicable since they're allowed to use their native language in class; (f) the lack of use in learning media, and (g) the scoring system which focuses more on result instead of process (Allen, 2004).

The problems of learning Arabic in UIN Sultan Thaha Saifuddin Jambi are: 1) The difficulty in understanding Arabic modules, which results in boredom and lack of interest, 2) Grammar-translate method present no new variation or new alternative teaching method that are used for teaching, 3) The limited use of teaching media, which only includes textbooks, speeches, and whiteboards, 4) Lecturers never used Arabic as language of instruction. They hardly ever gave the students chance to practice the dialogue material, 5) the Medias owned by universities haven't fully used such as the computer lab which only usually used for learning information and technology, 6) the limited use of media in learning Arabic. Flashcard as an available media at school, aside from books, whiteboards, and computers, even so, lecturers more often used textbooks as their media, 7) the speech method that dominates the learning process, is considered monotonous and uninteresting for college students. There is also the different background and personalities of each students, which results in various differences of students grasp in Arabic language, usually caused by the lack of interest among those students.

Based on those problems, the learning media development for Arabic language with the help of computer media deemed important by the researchers as a solution, and can hopefully be an answer to help students learn Arabic better. This media-enhanced learning will also help lecturers in their teaching process, and give the college students a chance to relearn everything on their own. Multimedia development as a helping media is aimed to ease the learning process of college students, so that they will be able to logically process the given material and to give more variation to learning process.

To deal with these problems as well, researchers are interested in developing a learning model with the help of computer multimedia, in order to abridge the issues of learning Arabic, in hope to increase the college students' interest in learning Arabic, which in turn will also increase their score and achievement. This media-enhanced learning will also help lecturers in their teaching process, and give the college students a chance to relearn everything on their own. Multimedia development as a helping media is aimed to ease the learning process of college students, so that they will be able to logically process the given material and to give more variation to learning process (Aladdin, Hamat, \& Yusof, 2004; Sardi, 2009).

Based on that description, researchers tried to do a study and development on Arabic learning model using help of computer 
multimedia that are effective, efficient, and suitable for FTK in UIN Sulthan Thaha Saifuddin Jambi.

\section{METHOD}

The reason of using $R \& D$ approach being the nature of this research, which is beside to acquire learning theoretical data and descriptive images about real condition in Arabic language learning process at Faculty of Islamic Education and Teacher Training in UIN Sulthan Thaha Saifuddin Jambi, also try to develop or produce a computer multimedia-enhanced Arabic learning model.

Using this approach, it is hoped that the resulting product is relevant with the need of Arabic learning at Faculty of Islamic Education and Teacher Training in UIN Sulthan Thaha Saifuddin Jambi as well as becoming an alternative learning model which could solve the issues of linguistic studies in UIN Sulthan Thaha Saifuddin Jambi. This is suitable to the aim of using the $R \& D$ approach which is "to bridge the existing gap between the existing study researches with learning practice" (Gall, Borg, \& Gall, 1996).

In execution, Borg and Gall expressed ten activities which could be summarized into seven steps:

1. Research and information collecting. This step is an introductory study, the activities included are library studies which will be used as a base of developed model or product, class observation, and the planning or work strategies for the study product's research and development.

2. Planning. This is a phase to define the skills, setting the goals and learning sequence, and probability testing.

3. Develop preliminary forms of product revision. This preliminary testing's goal is to acquire the descriptive worthiness of a product.

4. Main field test and final product revision. During this step, the developed product is already applicable. This step is also known as the model validation test.
5. Dissemination and implementation. During this phase, the socialization of the development result, and the report which was given in scientific meeting so that the new developed model can be used and utilized, is done.

Meanwhile, the steps in this research include preliminary study, development, and testing. For further information, those steps are:

\section{Preliminary Study}

The analyzed aspects of this resurvey are (1) communication and teaching design made by and done by lecturers, (2) college students learning activity, (3) lecturers performance, (4) media, facility, and environment, (5) the goal of learning Arabic, (6) the characteristic or Arabic study, (7) issues in learning Arabic, (8) and the characteristics of college students learning Arabic. The result of this survey is used as a consideration material to develop Arabic language learning model using the help of computer multimedia for Faculty of Islamic Education and Teacher Training in UIN Sulthan Thaha Saifuddin Jambi, and adjusted with the field situation.

\section{Learning Model Development Phase}

The analyzed aspects of this phase are (1) learning plan, (2) the implementation of learning plan which includes the activities of lecturers and students, and (3) the learning result. These three aspects continuously monitored in every cycle as an evaluation and reflection material, with a follow-up act being the improvement either to the planning or implementation unto the next cycle.

The result of this phase is a model characterization on Arabic learning model which can be used as a guide for lecturers and characteristic implementation for a conductive Arabic learning model in order to improve the linguistic skill of college students in UIN Sulthan Thaha Saifuddin Jambi. 


\section{Model Validation}

During this phase, the validation test was done to the developed learning model result. The result of this validation test is hoped to acquire a conclusion which give a picture of the developed learning model result's characteristic, as seen from the affectivity, especially towards lecturers' performance, students learning activity, and limitations as well as superiority. To receive such results, during this validation test a planned limited testing group which results are then matched or compared with the wide testing group is required.

\section{RESULT AND DISCUSSION}

\section{The Development of Arabic Learning Multimedia}

The development process of Arabic leaning multimedia as a learning medium was made through four development phase which is analysis, design, development, implementation and trial of learning media. The analysis phase was done to gather the necessary data. Furthermore, the analysis phase was done in order to collect data about how the media concept is going to be made. Initial design used storyboard to ease the implementation of design planning; during the implementation, the translation from planning into design was actually done by using Microsoft Powerpoint. The final phase is testing, which was done by the material and media experts, as well as the testing done to the students of Faculty of Islamic Education and Teacher Training in UIN Sulthan Thaha Saifuddin Jambi. Based on those steps, a product in the model of Arabic learning media was created and fit to use as a study material.

Table 1. Percentage of Ideality and Quality Assessment Results Arabic Language Learning Multimedia

\begin{tabular}{cccc}
\hline Aerage & $\begin{array}{c}\text { Ideal } \\
\text { Average } \\
\text { Score }\end{array}$ & $\begin{array}{c}\text { Percentage } \\
\text { of ideality }\end{array}$ & Category \\
\hline 43,92 & 50 & 87,85 & $\begin{array}{c}\text { Very } \\
\text { Good }\end{array}$ \\
\hline
\end{tabular}

The feasibility of Arabic learning media product is deemed as fit and can be used in field testing after the validation test was done by the material and media experts. The average score gained by this developed Arabic learning multimedia in field testing is 43.92, making it fall into the 'fine' category with ideal percentage of $87.85 \%$. Based on these scores, this Arabic learning multimedia model is fit to be used as a learning medium.

\section{The Design of Arabic Language Learning Media by Using the Help of Computer Multimedia}

The designed learning model which is developed to increase the linguistic skill including speaking/ communicating in Arabic and Arabic grammar includes: (1) the study goal which consist of (a) standard competence, (b)basic competence, and (c) indicator, (2) learning material (3) learning activities, (4) source and learning media, and (5) evaluation.

The study goals consist of standard competence, basic competence, and indicator. Standard competence and basic competence have been set by Kemenag (Number 02 Year 2008), while indicator is a result of lecturers interpretation in detailing the basic competence. The study goals are meant to give students orientation in learning Arabic. Learning activities are developed trough six steps, orientation phase, ordering command phase, role exchange phase, structured practice phase, guided practice phase, and scoring. The study material is students' Arabic handbook. Learning media is the use of computer multimedia which according to standard Arabic learning material. And evaluations consist of process evaluation and result of learning in the form of written and spoken tests.

\section{The Implementation of Arabic Language Learning Media by Using the Help of Computer Multimedia}

The learning model implementation was done in two phases, the limited group test 
phase, and the wide group test phase. The implementation on limited group test phase was meant to acquire an ideal model which could increase student's grammatical and vocal communication by using multimedia learning. After the limited testing was done, the learning model was considered to be able to increase college students' grammatical and oral communication capabilities. While the wide testing wad done to see how the learning model at Faculty of Islamic Education and Teacher Training in UIN Sulthan Thaha Saifuddin Jambi was carried out. After five times of wide test phase, it was found that the developed learning model could increase students' linguistic capabilities for all student majors. From that, it is decided that the developed learning model is deemed worthy to be applied in all majors or faculty.

\section{The Effectiveness of Arabic Language Learning Media by Using the Help of Computer Multimedia}

The result of college students study analysis, after being implemented in studies developed on majors with $\mathrm{A}, \mathrm{B}$, and $\mathrm{C}$ type accreditation during the limited test group, states that the learning model which was developed have a significant results towards the increase of college students' linguistic capabilities. Furthermore, this developed learning model indicates that this model is more efficient in increasing students' abilities compared to the traditional methods used by lecturers.

\section{The Supportive and Resistive Factors of Arabic Language Learning Media by Using the Help of Computer Multimedia}

a. The Supportive Factors Which Could Influence the Developed Learning Model

1. The ever increasing amount of available high tech media which could be developed for the importance of studying in FTK in UIN Sulthan Thaha Saifuddin Jambi.

2. The awareness about the technological importance in supporting and facilitating learning and teaching process.

3. A high enthusiasm in innovation to use technology among Arabic language lecturers at Faculty of Islamic Education and Teacher Training in UIN Sulthan Thaha Saifuddin Jambi.

4. The high amount of computer ownership and students' familiarity with computers, due to their habit of accessing internet, playing games, playing videos/movies which uses computer as a media.

5. The high amount of initial readiness and capability in following the program.

6. The availableness of study materials and teaching media. Students have their Arabic textbook as a source material. And the lack in media utilization is balanced by lecturer's use of linguistic lab.

7. A supportive attitude by the leaders to improve and implement this learning model. Especially in FTK UIN Sulthan Thaha Saifuddin Jambi which was used as a limited test location.

8. The conductive environment of FTK UIN Sulthan Thaha Saifuddin Jambi to implement the developed learning model so it can increase college students' linguistic capabilities without disturbing other classes in the process.

b. The Resistive Factors Which Could Influence The Developed Learning Media

1. The low amount of attention and frequency of activity by the researchers in Arabic language learning field to research and developed an approach and model, as well as a method of learning Arabic supported by multimedia.

2. The needed fund required for development and implementation is not available

3. The lack of programmer, and media learning designer at Faculty of Islamic Education and Teacher 
Training in UIN Sulthan Thaha Saifuddin Jambi whom can work as a team to develop this model.

4. A special classroom provided with required media to implement this model is not yet available

5. Technological facility such as computer, LCD projector, screen, and electrical installation on every classroom is currently unavailable; making implementing this model becomes harder.

6. The low lecturers' skills in using multimedia facility to operate the required technology that supports the implementation of this model

7. The limited professional competence of Arabic language lecturers in understanding Arabic language curriculum, Arabic language learning plan, learning material development, learning strategy and method development, and Arabic language learning evaluation selection.

The research discussions in this study are: The Arabic language learning model by using the help of computer multimedia needed lecturers whom have positive attitude towards IT in their teaching and an understanding of technological potential especially computers in order to increase the effectiveness of learning process, and also have the capabilities required to operate those media tools in learning process.

The Arabic language learning model by using the help of computer multimedia has an implication towards the use of computers in FTK sufficiently. The needed media components are, at least, a set of computers which have the specification and are able to operate other required tools such as LCD projectors, projector screen, and available electricity in every class, and more ideally is a class which is equipped with these tools. The learning process using this model requires sufficient fund to cover the completeness of of IT facility, training fund, and workshop that aimed to increase lecturers' qualifications.
The Arabic language learning model by using the help of computer multimedia requires future research and development to produce Arabic learning software/multimedia. That implies the increase in research projects and program development toward media based learning by the relevant institution.

Learning with the Arabic language learning model by using the help of computer multimedia, will change the perception of Arabic language lecturers towards the learning or Arabic which they've done so far by explaining the grammar, translating it into Bahasa Indonesia, and memorizing numerous vocabularies by giving the comprehensible input and giving them the chance to produce the words vocally.

\section{CONCLUSION AND RECOMMENDATION}

Based on the research result and discussion result, it can be concluded that this development research have been done according to the rules and procedure of research which have been set, but the obtained result also state that is not a perfect learning model. This is due to the limits in this research which is the learning model was only based on Arabic language learning process at FTK UIN STS Jambi. As such, it is recommended that the next researchers do a similar test and approach with wider and more varied subjects. With wider and more varied subjects, it is hoped that the valuable input to learning Arabic could be given. And also to conduct further research in order to develop learning with the help of computer multimedia which includes whole Arabic material, so that it will enrich the alternatives and learning models for Arabic language lecturers in FTK UIN Sulthan Thaha Saifuddin Jambi.

\section{REFERENCES}

Abdalla, M. (2010). The place of media in the arabic curriculum. In Arabic and the Media (pp. 253-290). Brill. 
Abdullah, M. S., \& Pathan, A.-S. K. (2013). Learning Qur'anic Arabic through interactive web-based software: A pragmatic approach in Language for Specific Purpose. In Information and Communication Technology for the Muslim World (ICT4M), 2013 5th International Conference on (pp. 1-6). IEEE.

Aladdin, A., Hamat, A., \& Yusof, M. S. (2004). Penggunaan PBBK (Pembelajaran Bahasa Berbantukan Komputer) dalam pengajaran dan pembelajaran Bahasa Arab Sebagai bahasa asing: Satu Tinjauan Awal. GEMA Online Journal of Language Studies, 4(1).

Aldalalah, M., Fong, S. F., \& Ababneh, W. Z. (2010). Effects of multimedia-based instructional designs for Arabic language learning among pupils of different achievement levels. International Journal of Human and Social Sciences, 5(5), 311-317.

Allen, R. (2004). Perspectives on Arabic teaching and learning. The Modern Language Journal, 88(2), 275-278.

Al-Shemri, Z. (2005). The questions of Arabic curriculum of the first grade (middle cycle) and their effect on developing thinking skills among female students according to Bloom's taxonomy of cognitive goals. Studies in Curriculum and Teaching Methods, 107, 93-141.

Amaliati, S. (2014). Implementasi kebijakan kurikulum berbasis turats pada mata kuliah bahasa arab dan nahwu program studi pendidikan Bahasa Arab di Institut Keislaman Abdullah Faqih Gresik. Jurnal Kebijakan Dan Pengembangan Pendidikan, 2(1).

Azhar, A. (2004). Bahasa Arab dan Metode Pengajarannya. Yogyakarta: Pustaka Pelajar.
England, L., Wahba, K., \& Taha, Z. A. (2014). Handbook for Arabic language teaching professionals in the 21 st century. Routledge.

Firmansyah, A. U. (2015). Rancang bangun aplikasi media pembelajaran Bahasa Arab berbasis multimedia dengan menggunakan Adobe Flash CS6 PAda Kelas VII Madrasah Tsanawiyah Islamiyah Hessa Air Genting. Jurteksi Royal Vol 2 No 1, 2.

Gall, M. D., Borg, W. R., \& Gall, J. P. (1996). Educational research: An introduction. Longman Publishing.

Godwin-Jones, R. (2012). Emerging technologies for language learning. The Encyclopedia of Applied Linguistics.

Hanifah, U. (2011). Media pembelajaran bahasa Arab. Putra Media Nusantara.

Mahmudah, S. (2018). Media pembelajaran Bahasa Arab. An Nabighoh Jurnal Pendidikan dan Pembelajaran Bahasa Arab, 20(01), 129-138.

Mohamed, W., Elbert, T., \& Landerl, K. (2011). The development of reading and spelling abilities in the first 3 years of learning Arabic. Reading and Writing, 24(9), 1043-1060.

Rehani, R. (2015). Students' perceptions on professional competence of lecturers at the department of Arabic Education, Faculty of Islamic Education and Teacher Training, State Institute for Islamic Studies IB Padang. Al-Ta Lim Journal, 22(1), 33-43.

Ryding, K. C. (2013). Teaching and learning Arabic as a foreign language: A guide for teachers. Georgetown University Press.

Samy, W. (2006). Instructional media and learning Arabic. Chap, 19, 263-274.

Sardi, J. (2009). Pembelajaran nahu dalam bahasa arab komunikasi 
menggunakan aplikasi multimedia berasaskan web (PhD Thesis). Jabatan Bahasa Arab dan Bahasa-bahasa Timur Tengah, Fakulti Bahasa dan Linguistik, Universiti Malaya.

Taha-Thomure, H. (2008). The status of Arabic language teaching today.
Education, Business and Society: Contemporary Middle Eastern Issues, 1(3), 186-192.

Wekke, I. S. (2015). Arabic teaching and learning: A model from Indonesian muslim minority. Procedia-Social and Behavioral Sciences, 191, 286-290. 